\title{
HISTORIA OCHRONY ŚRODOWISKA W ROSJI. RYS PRAWNO-PORÓWNAWCZY.
}

\section{HISTORY OF ENVIRONMENTAL PROTECTION IN RUSSIA. A LEGAL AND COMPARATIVE VIEW.}

\section{STRESZCZENIE}

Rosja jest krajem dysponującym największymi na świecie zasobami naturalnymi: ogromną międzykontynentalną przestrzenią obfitującą w rzeki, lasy, dziką zwierzynę i złoża cennych kopalin. Gospodarowanie i ochrona zasobów naturalnych od dawna były przedmiotem prawnych unormowań. Wraz z rozwojem cywilizacyjnym, przemianami społeczno-gospodarczymi i ustrojowymi prawo to ulegało istotnym przekształceniom. Zmieniał się cel, przedmiot oraz forma i sposób uregulowań.

W niniejszym artykule zostanie przedstawiona geneza i rozwój źródeł prawa związanych z szeroko rozumianym pojęciem środowi-

" Doktor nauk prawnych, Kujawsko-Pomorska Szkoła Wyższa w Bydgoszczy. 
ska - od początku rosyjskiej państwowości do upadku Związku Radzieckiego. Celem tego artykułu jest również dokonanie szkicu porównawczego w zakresie najbardziej charakterystycznych podobieństw i różnic w kształtowaniu się prawnych podstaw ochrony środowiska w Rosji i Polsce na przestrzeni dziejów.

\section{Słowa kluczowe} dowiska.

Rosja; historia ochrony środowiska; nacjonalizacja zasobów śro-

\section{ABSTRACT}

Russia is a country in possession of most natural resources in the world: a vast region spanning two continents, rich in rivers, forests, wild animals and mineral deposits. The management and protection of natural resources have been legally regulated for a long time. The law has undergone significant changes due to industrial development and transformation both socio-economic and political. The aim, the object, the form and the method of the regulations have been changing. This article will present the sources and development of the law concerning the environment in a wide sense - from the beginning of the Russian state to the fall of the Soviet Union. The aim of this article is also to present a legal and comparative view, i.e. to look at the most characteristic similarities and differences in environment protection in Russia and Poland, over a given time period.

\section{Keywords}

Russia; environmental protection history; nationalization of natural resources.

\section{UWAGI WSTĘPNE}

Rosja jest krajem dysponującym największymi na świecie zasobami naturalnymi: ogromną międzykontynentalną przestrzenią, obfitującą w rzeki, lasy, dziką zwierzynę i złoża cennych kopalin. Gospodarowanie i ochrona zasobów naturalnych 4/2015 od dawna były przedmiotem prawnych unormowań. Wraz z roz- 
wojem cywilizacyjnym, przemianami społeczno- gospodarczymi i ustrojowymi prawo to ulegało istotnym przekształceniom. Zmieniał się cel, przedmiot oraz forma i sposób uregulowań.

W niniejszym artykule zostanie przedstawiona geneza i rozwój źródeł prawa związanych z szeroko rozumianym pojęciem środowiska - od początku rosyjskiej państwowości do upadku Związku Radzieckiego. Celem tego artykułu jest również dokonanie szkicu porównawczego w zakresie najbardziej charakterystycznych podobieństw i różnic w kształtowaniu się prawnych podstaw ochrony środowiska w Rosji i Polsce na przestrzeni dziejów.

\section{SPOŁECZEŃSTWA PIERWOTNE I MONARCHIA WCZESNOFEUDALNA}

W okresie kiedy rozpoczęła się historia Rosji ludzkość zasiedlała Ziemię bardzo nierównomiernie ${ }^{1}$. Plemienne wspólnoty zamieszkujące tereny przyszłej Rosji zajmowały zasadniczo podstawowe typy środowisk: step i las, tworząc przy tym dwie odmienne kultury - azjatycką i europejską. Każdy lud miał własną gospodarkę i własny sposób utrzymania związany ze środowiskiem, które go żywiło².

Mieszkańcy bezkresnych stepów byli przede wszystkim dobrymi myśliwymi i pasterzami. Szerokie zróżnicowanie gatunków pasterskich (bydło, trzoda chlewna, owce, konie, kozy, renifery) umożliwiało im pełne wykorzystanie pastwisk. Przejście w czasach sowieckich na intensywny wypas ograniczający się tylko do gatunku owiec doprowadziło do zniszczenia i pustynnienia pastwisk.

Dla azjatyckich koczowników ogromną wartość miały wszelkie źródła wody. Dlatego to właśnie ochrony wód dotyczą najdawniejsze zasady prawa zwyczajowego, które później znalazły swoje odzwierciedlenie w Jasie Czyngischana, tj. pomniku

1 L. Gumilow, Od Rusi do Rosji, Warszawa 1996, s. 19.

2 Ibidem. 
prawodawstwa mongolskiego z przełomu XII i XIII wieku. Artykuły Jasy stanowią m.in: „kto moczy się w wodzie - śmierć, zakazuje się czerpać wodę do picia ręką, można ją brać tylko naczyniem, zakazuje się prać odzieży w wodzie, nawet jeśli z powodu brudu nie nadaje się ona do noszenia ${ }^{3 "}$. Ponadto Jasa Czingishana zawiera przepisy dotyczące uboju zwierząt oraz zakazuje kradzieży koni: „ten u kogo znajdzie się skradziony koń powinien oddać go właścicielowi dokładając 10 takich koni, a jeśli nie jest w stanie wypełnić tej kary zamiast koni należy odebrać mu dzieci, a jeśli nie ma dzieci - jego samego zarżnąć jak barana".

Natomiast w obfitych w wodę, liściastych puszczach Europy środkowowschodniej i wschodniej osiedliły się plemiona słowiańskie będące nośnikiem etnosu europejskiego. W odróżnieniu od Azjatów, którym warunki środowiskowe uniemożliwiały uprawę ziemi, podstawą gospodarki Słowian już od V wieku było nie pasterstwo i myślistwo, ale rolnictwo, co przyczyniło się do utrwalenia osiadłego trybu życia ${ }^{5}$. W wiekach VI-VII Słowianie - lud silny i energiczny - odnosili wielkie sukcesy. Przyrost naturalny był duży nie tyle dzięki monogamicznym małżeństwom, ale płodności kobiet ${ }^{6}$. W następnych stuleciach (VIII-IX w.) u plemion wschodniosłowiańskich nastąpił znaczny wzrost poziomu sił wytwórczych ${ }^{7}$. Jednakże, w odróżnieniu od cywilizacji stepu, cywilizacja Słowian oddziaływała na środowisko bardziej inwazyjnie. Rozszerzanie areału rolnego, rozwój warzywnictwa, uprawy lnu i konopi odbywały się kosztem puszczy, którą wypalano i zamieniano w pole uprawne.

3 А. Доманин, Монгольская империя Чингизидов. Чингисхан и его преемники [online], http://oldevrasia.ru/library/Aleksandr-Domanin_Mongolskaya-imperiya-CHingizidov--CHingiskhan-i-ego-preemniki/18; Великая Яса Ченгис-хана [online] http://samlib.ru/k/kucher_p_a/0011_velikajajasa.shtml.

4 Ibidem.

5 M. Szczaniecki, Powszechna historia państwa i prawa, Warszawa 2003, s. 48 .

6 L. Gumilow, op. cit., s. 26.

7 L. Bazylow, Historia Rosji, Warszawa 1996, s. 19. 
U Słowian, pomimo stopniowego zmniejszania się obszaru lasu, nadal dużą rolę odgrywały myślistwo, rybołówstwo oraz bartnictwo. Futra, skóry, wosk i miód były głównymi artykułami wymiennymi. Futra sprzedawano przede wszystkim na Zachód, gdzie brakowało zwierząt futerkowych, a gronostaje były tak rzadkie, że sporządzano $\mathrm{z}$ nich jedynie płaszcze królewskie ${ }^{8}$. Wiązki futer były też jednostkami pieniężnymi zanim do obrotu nie wszedł pieniądz metalowy ${ }^{9}$.

Wskutek narastającej tendencji zjednoczeniowej w IX wie$\mathrm{ku}$ na terenach zajmowanych przez plemiona wschodniosłowiańskie wyłoniło się państwo kijowskie występujące w źródłach pod nazwą Ruś ${ }^{10}$. Najdawniejszym pomnikiem prawa na Rusi jest Ruska Prawda z 1016 roku obejmująca normy zwyczajowe, ustawy monarsze i orzecznictwo sądowe. Pojawiła się ona o wiele wcześniej niż zbiory praw w innych krajach europejskich $^{11}$. W Polsce $\mathrm{z}$ tego okresu brak jest niemal zupełnie źródeł bezpośrednich, zachowały się tylko źródła opisowe ${ }^{12}$.

Tekst Ruskiej Prawdy zawiera przepisy dotyczące korzystania ze środowiska. Obejmuje ochroną las jako własność księcia, przewiduje kary za zniszczenie drzew bartnych. Zakazuje, pod groźbą kary pieniężnej, kradzieży drewna, siana, ptactwa domowego i drapieżnego oraz zwierząt gospodarskich ${ }^{13}$. Za kradzież bobra Ruska Prawda przewiduje taką samą karę jak za zabicie chłopa - 12 grzywien. Najsurowszą przewidywaną karą, to jest wygnaniem i konfiskatą mienia (potok i rozgrablenije), karze podpalaczy gospodarstw i dworów ${ }^{14}$. Ruska Prawda ochrania nie tyle same obiekty, na przykład drzewa bartne, pszczoły, bobry, co prawo własności do nich. Akt ten odegrał ważną rolę w późniejszym rozwoju prawa w Europie Środkowo-Wschod-

8 L. Gumilow, op. cit., s. 19.

9 L. Bazylow, op. cit., s. 19.

10 K. Koranyi, Powszechna historia prawa, Warszawa 1976, s. 122.

11 S. Płaza, Historia prawa w Polsce na tle porównawczym, Kraków 1997, s. 7.

12 Ibidem.

13 Powszechna historia państwa i prawa. Wybór tekstów źródłowych, wyboru dokonali M. J. Ptak i M. Kinstler, Wrocław 1999, s. 362.

14 Ibidem, s. 368. 
niej, na nim były wzorowane źródła polskie: statut wiślicki, statut Kazimierza IV Jagiellończyka i statuty litewskie. Ruska Prawda obwiązywała do przełomu XV i XVI wieku, kiedy to zastąpiły ją ogólnorosyjskie kodyfikacje powszechne - Sudiebnik z 1497 roku i następnie Carski Sudiebnik z 1550 roku ${ }^{15}$.

\section{OKRES ROZDROBNIENIA FEUDALNEGO I MONARCHII STANOWEJ}

Okres rozdrobnienia feudalnego trwał na Rusi od XII do XV wieku. Wykazywał on wiele zbieżności z rozbiciem dzielnicowym w Polsce, które nastąpiło po śmierci Bolesława Krzywoustego. Ważnymi źródłami prawa stały się wówczas statuty książęce, czyli tzw. gramoty. Dokumenty te nadawały ziemię książęcą określonym podmiotom, przede wszystkim zaś monastyrom, określając przy tym zasady dotyczące korzystania ze środowiska, a w szczególności: polowań, wyrębu lasu, bartnictwa i rybołówstwa. I tak na przykład w XV wieku biełozierski kniaź Michaił Andrejewicz podarował monastyrowi Kiryła monopol na połów ryb w Jeziorze Ułomskim, a wielki kniaź moskiewski Wasyl I Rurykowicz zakazał swoim rybakom łowić w jeziorach Monastyru Konstantynowskiego ${ }^{16}$. W późniejszych czasach pojawiły się też gramoty innego typu. Na przykład w statucie Wasyla III z 1530 roku został uchylony zakaz wyrębu lasu przynależnego do prywatnych właścicieli, jeśli pozyskane drewno przeznaczone było do procesu warzenia brakującej w tym okresie soli ${ }^{17}$.

Podobnie jak w Polsce początkowo prawo do polowań przysługiwało każdemu ${ }^{18}$. Później kniaziowie stopniowo ogra-

15 K. Koranyi, op. cit., s. 225.

16 М. Б. Булгаков, А. А Ялбулганов, Природоохранные акты: от «Русской правды» до петровских времен, „Государство и право” 1996, nr 2, s. 52.

17 Ibidem.

18 W. Radecki, Zarys historii prawnej ochrony przyrody w Polsce, w: Prawne formy ochrony przyrody, pod red. J. Sommera, Warszawa 1990, cyt. za J. Boć, K. Nowacki, E. Samborska-Boć, Ochrona środowiska, Wrocław 2008, s. 12. 
niczali powszechne prawo polowania. Jednakże w odróżnieniu od występujących w Polsce regaliów, czyli przywilejów łowieckich na określony gatunek zwierzyny (bobry, niedźwiedzie, tury, żubry), na Rusi, z powodu większej obfitości zwierząt, ograniczenia te dotyczyły konkretnych obszarów - wybranych, najzasobniejszych łowisk ${ }^{19}$. Do XV wieku największą ilość futer pozyskiwano na zachodzie kraju. Na bobry i łasice polowano w lasach liściastych, których w tych szerokościach geograficznych wciąż jeszcze było pod dostatkiem. W owym czasie wartość skóry bobra równała się wartości 1-2 koni roboczych lub 2-4 krów. Zwierzęta te łapano za pomocą wnyków i specjalnie ułożonych psów, najczęściej z rasy łajek. Znając ówczesną wartość bobrowej skórki nie dziwi fakt, że także i w Polsce bóbr, już od czasów Bolesława Chrobrego, objęty został ochroną ${ }^{20}$.

Podobnie jak w Polsce prawo tego okresu nadal chroniło przede wszystkim obiekty naturalne stanowiące własność książąt i monastyrów przed wykorzystywaniem ich przez osoby nieuprawnione. W tym okresie nie było jeszcze mowy o ochronie zasobów we współczesnym rozumieniu. Jednakże obiektywnie rzecz biorąc prawodawcza działalność książąt zapobiegała nadmiernej eksploatacji zasobów środowiska.

U schyłku rozdrobnienia feudalnego zaczęły wzmacniać się tendencje integracyjne i wzrosła rola Wielkiego Księstwa Moskiewskiego. Pod koniec XV wieku kniaziom moskiewskim z rodu Rurykowiczów udało się doprowadzić do ponownego zjednoczenia ziem ruskich ${ }^{21}$. W okresie monarchii stanowej, trwającej w Rosji od XVI wieku do połowy XVII, ważną rolę odgrywały ukazy carskie i w tej właśnie formie reglamentowano korzystanie z zasobów przyrody. Jako przykład wskazać można ukaz cara Iwana Groźnego z 1571 roku w sprawie ochrony lasów zasiekowych ${ }^{22}$. Jest to ciekawa forma ochrony rezerwatowej

19 Źródło: История русской охоты [online], http://www.oxotarus.ru/hunting_history.html.

${ }^{20}$ J. Boć, K. Nowacki, E. Samborska-Boć, Ochrona środowiska, Wrocław 2008, s. 12.

${ }^{21}$ M. Sczaniecki, op. cit., s. 198.

22 М. М. Бринчук, Экологическое право. Учебник, КонсультантПлюс 2009, e-book: https://books.google.pl/. 
niewystępująca w naszym kraju. Chodzi o gęste lasy położone wzdłuż południowej granicy państwa stanowiące naturalną zaporę przeciwko atakom wrogich wojsk. Nie było możliwości, aby móc przejechać konno, a tym bardziej z wozami i obozem, przez zasieki utworzone z powalonych, wielkich drzew. Ze względu na stale grożące napady Tatarów i Turków wprowadzono więc surowy zakaz wycinania i usuwania powalonych drzew, jeżdżenia tam konno i wozami. W drodze wyjątku dopuszczano jedynie bartnictwo, ale bez tworzenia dróg oraz ścieżek, które można by przebyć na koniu. Dostępu do lasu strzegły straże - za naruszenie zakazu groziła kara śmierci. Wagę lasów zasiekowych dla obrony bezpieczeństwa państwa potwierdził kolejny akt prawny. Zgodnie z ukazem z 1678 roku, wydanym przez cara Fiodora III Romanowa, za wyrąb lasu w strefie przygranicznej przywidziana była grzywna 10 rubli i kara knuta wymierzana bez zmiłowania. Powtórne naruszenie zakazu karano śmiercią ${ }^{23}$.

Były także i inne przyczyny dbałości o las, a mianowicie związane z ochroną siedlisk zwierzyny. Łowiectwo w Rosji miało bowiem ogromne znaczenie nie tylko jako dodatkowe źródło pożywienia i skór czy jako rozrywka elit, ale stanowiło jedno z najważniejszych źródeł dochodu narodowego. Do XVI wieku Rosja była $\mathrm{w}$ bowiem jedynym krajem świata dostarczającym futra na rynek międzynarodowy. Na eksport szły skóry soboli, wiewiórek, bobrów i łasic. Rozpoczęta w XVII wieku ochrona leśnych masywów Syberii związana była właśnie z rzemiosłem futrzarskim. I tak w 1681 roku wydany został carski ukaz dla Jakucji: „nie palić, nie ciąć lasów żeby zwierz nie uciekł”. Kiedy w XVII wieku wyraźnie zaczęła zmniejszać się liczebność sobola (co roku pozyskiwano bowiem aż jedną trzecią jesiennej populacji) w celu poprawy stanu gatunku wyznaczono na Syberii rezerwaty obejmujące obszar powiatu ketskiego oraz nadbrzeża rzeki Angary. Ponadto chroniono lasy w celach przeciwpowodziowych: „na brzegach rzeki Dwiny lasu nie ciąć, drew nie rąbać, łyka nie drzeć" - stanowił ukaz Iwana Groźnego z 1563 roku $^{24}$.

24 Ibidem. 
Odnośnie myślistwa Iwan I Romanow wydał w 1635 roku carski ukaz o zakazie pozyskiwania wydry i bobra za pomocą wnyków, a następnie - o zakazie polowań z sokołem i z psami (z wyjątkiem polowań carskich) w lasach podmoskiewskich. Jego syn Fiodor III Romanow, wielki miłośnik polowań, objął ochroną rezerwatową 8 podmoskiewskich wysp stanowiących siedliska sokoła - białozora, którego nie mógł łowić nikt prócz samego cara ${ }^{25}$.

Natomiast pierwszym aktem regulującym zasady rybactwa był ukaz cara Michaiła I Romanowa z 1632 roku o połowach w jeziorze Nero. O jego istnieniu wiadomo wszakże tylko z $L a-$ topisu celijnego św. Dymitra Rostowskiego, sam tekst ukazu nie zachował się. Natomiast w wydanej w 1649 roku kolejnej kodyfikacji prawa ogólnorosyjskiego, czyli w tzw. Sobornym Uło$\dot{z} e n i j u^{26}$, za połów ryb $\mathrm{w}$ cudzym stawie przewidywano bicie batogami, a przy ponownym przyłapaniu na tym występku - bicie knutem, za trzecim zaś razem - odcięcie ucha. W 1669 roku sankcje jeszcze zaostrzono - przez ucięcie dłoni lewej ręki. W 1676 roku ukazał się carski akt reglamentujący rybactwo w Jeziorze Pleszczejewo. Dla ochrony śledziowatych wprowadzono zakazy połowu młodych ryb i zakaz używania dużych niewodów. Przewidziano też okresy ochronne. Za naruszenie zakazu groziła kara śmierci. Tak surowa sankcja była związana z tym, że ryby z tego jeziora trafiały na carski stół ${ }^{27}$.

Także polscy monarchowie tego okresu ze szczególną troską odnosili się do zasobów zwierzyny łownej oraz do stanu lasów. Kwestie te zostały szczegółowo udokumentowane między innymi w statutach wareckich i krakowskich oraz statutach litewskich ${ }^{28}$.

Z przeglądu źródeł prawodawstwa ochronnego monarchii stanowej w Rosji wynika dbałość już nie tylko o własność

25 Н. И. Кутепов, Царская охота на Руси, Санкт Петербург 1894, e-book: http://www.litmir.info/bd/?b=200751.

26 D. Czerska, Sobronoje Ułożenije 1649 roku. Zagadnienia społeczno-ustrojowe, Wrocław 1970, s. 45.

27 М. М. Бринчук, op. cit., e-book: https://books.google.pl/.

28 J. Boć, K. Nowacki, E. Samborska-Boć, Ochrona środowiska, Wrocław 2008, s. 12. 
książęcą oraz własność prywatną, ale wraz z odrodzeniem się carstwa pojawia się ochrona obiektów naturalnych $\mathrm{w}$ interesie obronności państwa (lasy zasiekowe) oraz w interesie ekonomicznym - zyski z międzynarodowego handlu futrem wydry i bobra oraz podatki za pozyskiwanie sobola z należących do cara lasów Syberii. Ponadto w tym okresie, podobnie jak i w Polsce, pojawiły się też pierwsze przepisy mające charakter ochrony sanitarnej. I tak, zgodnie z ukazem Michała I Romanowa z 1640 roku, w celach profilaktycznych wymagano, aby padłe konie i wszelkie zwierzęta gospodarskie grzebać głęboko w ziemi, za miastem, na terenach wolnych i aby nie pozostawiać padłych zwierząt domowych, żeby padlina i kotów psów „nie walała się po ulicach"29.

\section{OKRES MONARCHII ABSOLUTNEJ I IMPERIUM ROSYJSKIEGO}

Druga połowa XVII wieku, a w jeszcze większym stopniu wiek XVIII, to czas umacniania się międzynarodowej potęgi politycznej Rosji oraz głębokich reform sięgających wszystkich dziedzin życia wewnętrznego w kraju ${ }^{30}$. Reformy przeprowadzane za panowania Piotra I i Katarzyny II w pewnym zakresie wiązały się również z kwestiami środowiskowymi. I tak Piotr I swoimi ukazami zabronił wycinania lasów wzdłuż rzek, po których odbywał się spław drewna, niektóre lasy objął ochroną rezerwatową i zabronił wycinania pewnych gatunków drzew. Katarzyna II rozwinęła rozpoczętą przez Michała I Romanowa ochronę sanitarną: w akcie o zarządzaniu guberniami z 1775 roku nałożyła na isprawników ziemskich, czyli wybieranych przez szlachtę urzędników pełniących funkcje administracyjno-policyjne w powiatach, odpowiedzialność za dopilnowanie czystości na drogach i we wsiach. Wydany przez cesarzową statut o policji

29 M. М. Бринчук, op. cit., e-book: https://books.google.pl/.

30 M. Sczaniecki, op. cit., s. 288. 
z 1782 roku nakładał na dowódców jednostek obowiązek dopilnowania czystości na ulicach miast ${ }^{31}$.

Władcy Rosji tego okresu tradycyjnie przywiązywali dużą uwagę do kwestii łowiectwa i zwierzyny. Kiedy w wyniku III rozbioru Polski puszcza Białowieska weszła w skład Imperium Rosyjskiego, rozpoczęta przez polskich królów ochrona tego obszaru była kontynuowana przez kolejnych carów. 22 października 1802 roku imperator Aleksander I wydał ukaz obejmujący ochroną żubry oraz obszar puszczy wprowadzając zakaz wycinania drzew, zakaz strzelania do żubrów i nanoszenia im wszelkich innych szkód. Przy czym samego cara i jego rodziny oraz gości te zakazy nie tyczyły $\mathrm{się}^{32}$. W carskim rezerwacie populacja żubrów osiągnęła w roku 1857 rekordową liczbę 1900 osobników ${ }^{33}$. Przychylność wobec doskonalenia zasad łowiectwa widać było także w przyzwoleniu władz carskich, zasadniczo niechętnych tworzeniu się polskich organizacji, na założenie w 1889 roku Towarzystwa Prawidłowego Myślistwa w Warszawie. Hodowla i ochrona zwierząt tratowane były tam jako integralne składniki łowiectwa na równi z propagowaniem zasad etyki i racjonalnego polowania ${ }^{34}$. Pod zaborem rosyjskim powstały także inne ważne organizacje działające na polu szeroko rozumianej ochrony środowiska takie, jak m.in. Towarzystwo Opieki nad Zwierzętami założone w Warszawie w 1864 roku pierwsza polska organizacja społeczna działająca w sposób ciągły do dzisiaj ${ }^{35}$ oraz Warszawskie Towarzystwo Higieniczne założone w marcu 1898 roku $^{36}$.

Już za czasów Piotra I Rosja była widownią poważnego rozwoju przemysłu. Początkowo rozwijał się on w manufaktu-

31 М. М. Бринчук, op. cit., e-book: https://books.google.pl/.

32 Podczas tylko jednego carskiego polowania w dniach 6 i 7 października podczas car Aleksander II osobiście zabił 10 żubrów, 2 łosie, 10 kóz, 8 łani, 5 wilków, 5 lisów, 1 dzika i 1 borsuka. Źródło: http://www.oxota-ru.ru/articles/ohota-v-belarusi-lishnie-zubry.

33 Białowieski Park Narodowy [online] http://bpn.com.pl/index.php?option $=$ com_content $\&$ task $=$ view $\&$ id $=52 \&$ Itemid $=103$

34 R. Paczuski, Prawo ochrony środowiska, Bydgoszcz 2000, s. 253.

35 Źródło: http://www.toz.pl/.

36 Źródło: http://www.pth.pl/. 
rach zarówno szlacheckich, jak i państwowych, a opierał się głównie na pracy chłopów pańszczyźnianych oraz posesyjnych ${ }^{37}$. Niemniej jednak już w pierwszej połowie XIX wieku industrializacja uczyniła na tyle istotne postępy, że koniecznym stało się wydanie pierwszych regulacji ograniczających emisje do środowiska. Car Mikołaj I wydał w 1833 roku akt pod nazwą: Zasady rozmieszczenia i organizacji prywatnych zakładów, manufaktur, fabryk i innych przedsiębiorstw $w$ Sankt Petersburgu, według którego należało bezwzględnie unieszkodliwiać wydzielające się szkodliwe gazy produkcyjne metodą spalania. W tymże dokumencie zakłady przemysłowe zostały podzielone na trzy kategorie ze względu na szkodliwość emisji do powietrza, przy czym przedsięwzięcia trzeciej kategorii nie mogły być lokalizowane $\mathrm{w}$ mieście ${ }^{38}$.

W 1845 roku został ogłoszony nowy kodeks karny pod nazwą Kodeks kar głównych i poprawczych ${ }^{39}$. Przewidywał on kary aresztu od 7 dni do 3 miesięcy i grzywny nie wyższej niż 300 rubli wobec właścicieli zakładów i fabryk w mieście, a także poza miastem, których działalność powodowałaby zanieczyszczenie powietrza i rzek. Szkody w środowisku miały być usuwane na koszt właścicieli ${ }^{40}$. Te przykłady dowodzą, że wbrew powszechnej opinii, przynajmniej pod względem regulacji prawnych, Rosja nie odstępowała od najbardziej uprzemysłowionych państw Europy Zachodniej. Pierwsza holenderska ustawa o ograniczeniu zanieczyszczeń przemysłowych wydana została bowiem w 1875 roku, a rok później ukazała się w Anglii ustawa o ochronie rzek przed zanieczyszczeniami ${ }^{41}$.

Jednakowoż dopiero przy Aleksandrze II, dzięki zniesieniu w 1861 roku poddaństwa, dziesiątki milionów rosyjskich chłopów zyskało wolność osobistą i mogło wyjechać do pracy w rozwijających się wielkich zakładach. Pod koniec XIX wieku ponad 2 miliony ludzi było zatrudnionych w fabrykach i kopal-

37 M. Sczaniecki, op. cit., s. 472.

38 M. М. Бринчук, op. cit., e-book: https://books.google.pl/.

39 K. Koranyi, op. cit., s. 360.

40 M. М. Бринчук, op. cit., e-book: https://books.google.pl/.

41 R. Paczuski, op. cit., s. 28. 
niach, produkcja przemysłowa oraz budownictwo kolejowe rosły nieustannie. Najwięcej robotników pracowało w przemyśle włókienniczym, potem w ciężkim, spożywczym i ceramicznym, drzewnym oraz papierniczym. Najsilniejszymi ośrodkami przemysłowymi były: Zagłębie Donieckie (Donbas), okręg bakijski, okręg centralny (moskiewski), petersburski i Ural ${ }^{42}$. Uprzemysłowienie Rosji dokonywało się nierównomiernie ${ }^{43}$, gdyż - poza rejonami wysoce uprzemysłowionymi - większość kraju zachowała charakter wybitnie rolniczy ${ }^{44}$.

Na początku XX wieku po raz pierwszy została podniesiona kwestia powołania specjalnego organu dla kontroli przestrzegania norm środowiskowych. A w latach 1915-1916 opracowano projekt pierwszej rosyjskiej ustawy o ochronie przyrody - jednakowoż z powodu nadciągającej rewolucji projekty te nie zdążyły wejść w życie.

\section{OCHRONA ŚRODOWISKA W ZWIĄZKU RADZIECKIM}

Rewolucja październikowa otworzyła całkowicie nowy etap rozwoju państwa i prawa. W owym czasie dominowało przekonanie o konieczności wyrzucenia na „śmietnik historii” całego dorobku przedrewolucyjnego i zbudowania na gruzach przeszłości, a więc niejako ex nihilo, nowego porządku prawnego od samych podstaw ${ }^{45}$. Początkowo, wobec zakazu powoływania się na prawodawstwo carskie, sądy i administracja musiały kierować się tylko „dekretami rządu robotniczo-chłopskiego oraz sumieniem socjalistycznym"46. Okres pustki legislacyjnej nie trwał jednak zbyt długo, bo już w początku lat dwudziestych władza radziecka uchwaliła szereg aktów, w tym dotyczących

42 L. Bazylow, op. cit., s. 396.

43 Mieszkańcy wsi stanowili 3/4 ludności Rosji końca XIX wieku. Zob. L. Bazylow, op. cit., s. 396.

44 M. Sczaniecki, op. cit., s. 472.

45 K. Sójka-Zielińska, Historia prawa, Warszawa 1998, s. 367.

46 Ibidem, s. 367. 
środowiska. Najpierw jednak dekretem o ziemi ogłoszonym 8 listopada 1917 roku przez II Ogólnorosyjski Zjazd Rad przeprowadzono całkowitą nacjonalizację ziemi i jej bogactw. Własność prywatna ziemi i jej zasobów została zniesiona i wyjęta spod obrotu cywilnoprawnego ${ }^{47}$. Następnie ukazały się kodeksy i ustawy normujące gospodarowanie poszczególnymi zasobami naturalnymi: Kodeks ziemski Rosyjskiej Socjalistycznej Federacyjnej Republiki Radzieckiej (RSFRR) z 1922 r.; Kodeks leśny RSFRR z 1923 r.; dekrety Rady Komisarzy Ludowych RFSRR: o ochronie sanitarnej mieszkań z 1919 r.; o wnętrzu ziemi z 1920 r.; o łowiectwie z 1920 r.; o ochronie pomników przyrody, sadów i parków z 1921 r.; postanowienie Centralnego Komitetu Wykonawczego i Rady Komisarzy Związku Radzieckiego o organizacji gospodarstwa rybackiego Związku Radzieckiego z 1924 r. W ślad za kodeksami RFSRR postępowało ustawodawstwo republik związkowych.

W analogicznym okresie w Polsce, po odzyskaniu niepodległości również bardzo silnie aktywizowały się prace legislacyjne związane $\mathrm{z}$ ochroną środowiska. $\mathrm{W}$ dwudziestoleciu międzywojennym wydano w RP szereg ustaw o podobnym zakresie

47 Zob. Powszechna historia..., op. cit., s. 362.: „[...] 1. Prawo prywatnej własności ziemi znosi się na zawsze; ziemia nie może być ani sprzedawana, ani kupowana, ani oddawana w dzierżawę lub zastawiana, ani zbywana w jakikolwiek inny sposób. Wszystkie ziemie [...] zostają wywłaszczone bez odszkodowania, stają się mieniem ogólnonarodowym i przechodzą na użytkowanie wszystkich tych, którzy na nich pracują. Osobom, które z powodu przewrotu majątkowego poniosą straty, przyznaje się jedynie prawo do pomocy społecznej na czas niezbędny do przystosowania się do nowych warunków bytu. 2) Wszystkie bogactwa wnętrza ziemi: ruda, ropa naftowa, węgiel, sól itd., a także lasy, wody, posiadające znaczenie ogólnopaństwowe, przechodzą na wyłączne użytkowanie państwa. Wszystkie drobne rzeki, jeziora, lasy itd. przechodzą na użytkowanie gromad pod warunkiem, że zarządzać nimi będą lokalne organy samorządowe. 3) Grunta, na których istnieją gospodarstwa o wysokiej kulturze: sady, plantacje, hodowla rozsad, szkółki, oranżerie itp., nie podlegają podziałowi, lecz zostają przekształcone w gospodarstwa wzorowe i przechodzą na wyłączne użytkowanie państwa lub gromad, zależnie od swych rozmiarów i znaczenia. Miejskie i wiejskie działki zagrodowe wraz z ogródkami domowymi i sadami pozostają w użytkowaniu obecnych właścicieli, przy czym rozmiary samych działek i wysokość podatków za ich użytkowanie zostaną określone w drodze ustawodawczej". 
przedmiotowym choć odnosiły się one do odmiennych realiów własnościowych i politycznych. Pierwszą była ustawa sanitarna z 1919 r; następnie: wodna z 1922 r.; o prawie łowieckim z 1927 r.; o ochronie zwierząt z 1932 r.; - o ochronie przyrody z 1934 r. $\mathrm{i}$ in. ${ }^{48}$

W latach trzydziestych i w kolejnych dekadach socjalizmu środowisko naturalne ZSRR doznało niebywałych przeciążeń. Było to związane przede wszystkim z bezprecedensowo szybką industrializacją kraju. Do roku 1939 Związek Radziecki stał się trzecią potęgą przemysłową świata ${ }^{49}$. Pomiędzy rokiem 1929 a 1940 produkcja stali, cementu i węgla wzrosła 4-krotnie. Produkcja samochodów osobowych i ciężarowych wzrosła z 800 do 145000 rocznie. Produkcja statków, lokomotyw i traktorów również wzrastała w zdumiewającym tempie. Kampania produkcji większej ilości elektryczności, maszyn, żelaza, stali i węgla została zapoczątkowana przez Stalina. Pierwszy plan 5-letni zainaugurowano $\mathrm{w}$ roku 1928, a jego cele zostały osiągnięte w czasie znacznie krótszym. Po jego zakończeniu zaczęto realizować następny plan 5-letni. Priorytet uzyskały elektrownie węglowe i wodne. Wiele pól zniknęło pod dachami nowych fabryk, składów, bloków. W edukacji i w niektórych aspektach kultury i sztuki wyniki były również znaczne. Poziom analfabetyzmu, tak ogromny kiedy ostatni car wstępował na tron, został niemal całkowicie zlikwidowany. Szkolnictwo wyższe i techniczne było bezpłatne, przyciągając wielkie ilości zarówno kobiet, jak i mężczyzn. Gorliwie badano najnowsze osiągniecia techniczne i naukowe innych krajów. Najnowsze zagraniczne maszyny rozbierano na części i kopiowano ${ }^{50}$.

Propagandowe plakaty tamtych lat głosiły, że „dym kominów to oddech Rosji Radzieckiej”. Atmosferę towarzyszącą wielkim budowom socjalizmu świetnie oddaje również ówczesna poezja:

48 J. Boć, K. Nowacki, E. Samborska-Boć, op. cit., s. 14.

49 G. Blainey, A Short History of the Twentieth Century, Pinguin Books, Australia 2005, s. 81-83.

50 Ibidem. 


\section{[...] To Stalin lasy w pochód śle, rzekom w pustynie płynąć każe, Stalin - towarzysz, Stalin - wódz, Stalin - inżynier naszych marzeń ${ }^{51}$.}

Próbą wprowadzenia pewnych ograniczeń na eksploatację zasobów naturalnych była uchwalona dnia 27 października 1960 roku ustawa o ochronie przyrody RSFRR. Zawierała ona przepisy o ochronie gleby, wody, lasów świata roślin i zwierząt jednakowoż w praktyce nie odegrała poważnego znaczenia.

Do lat siedemdziesiątych problem ochrony środowiska był rozpatrywany w kontekście nie ekologicznym, ale sanitarnym, to jest z punktu widzenia wpływu na zdrowie i życie człowieka. Jednakże pod wpływem prawa międzynarodowego, w tym zwłaszcza konferencji Sztokholmskiej w ONZ zorganizowanej w czerwcu 1972 roku, nastąpił nowy etap rozwoju prawa ochrony środowiska w Związku Radzieckim. W latach siedemdziesiątych i osiemdziesiątych przyjęto wiele ustaw charakteryzujących się nowym, całościowym podejściem a mianowicie: kodeks ziemski RSFRR z 1970 r.; kodeks wodny RSFRR z 1972 r.; kodeks o wnętrzu ziemi RSFRR z 1976 r.; kodeks leśny RSFRR z 1978 r.; ustawa RSFRR o ochronie powietrza atmosferycznego z 1980 r.; ustawa RSFRR o ochronie i wykorzystywaniu świata zwierząt z 1982 roku. W analogicznym okresie także i do Polski przybyła fala nowych regulacji inspirowanych wynikami konferencji sztokholmskiej, największym osiągnieciem tego okresu jest uchwalenie pierwszej kompleksowej ustawy o ochronie i kształtowaniu środowiska z dnia 31 stycznia 1980 r. $^{52}$

W latach osiemdziesiątych stało się jasne, że dotychczasowe wysiłki legislacyjne mające na celu zapewnienie bardziej racjonalnego korzystania ze środowiska nie przyniosły oczekiwanych rezultatów, a stan środowiska w ZSRR ulegał ciągłemu pogorszeniu. Na terytorium państwa pojawiły się obszary noszą-

51 K. Gruszczyński, Stalin, inżynier naszych marzeń, Trybuna Ludu z 1949 r. [online].

52 Dz.U. z 1980 r. Nr 3, poz. 6. 
ce znamiona klęski ekologicznej, tzw. „zony”53. Przyczyną tego stanu była słabość regulacji prawnych, brak efektywnego pionu organizacyjnego kontrolującego przestrzeganie norm środowiskowych, brak dostatecznego finansowania działalności prośrodowiskowej, brak jakichkolwiek stymulatorów ekonomicznych dla unowocześniania technologii przedsiębiorstw w kierunku oszczędności zasobów i zmniejszania szkodliwych emisji ${ }^{54}$.

Nowy etap rozwoju prawa ochrony środowiska, tzw. prawa ekologicznego, związany jest już z rozpadem Związku Radzieckiego i przejściem z gospodarki uspołecznionej do wolnorynkowej. Jednakże jego omówienie nie mieści się $\mathrm{w}$ ramach założonych dla tego artykułu i wymaga osobnego opracowania.

\section{PODSUMOWANIE}

Podsumowując dokonane ustalenia, stwierdzić należy, że ochrona środowiska w Rosji, podobnie jak i w Polsce, ma długą tradycję sięgającą początków państwowości. Jednakowoż źródła prawa staroruskiego powstały nieco wcześniej, a mianowicie już w początku XI wieku. Analogicznie jak w naszym kraju przedmiotem początkowych regulacji była ochrona obiektów przyrodniczych: lasów, zwierzyny jako własności władców i książąt. W odróżnieniu od istniejącego w polskiej monarchii wczesnofeudalnej systemu regaliów - monopole łowieckie w Rosji dotyczyły określonych łowisk. Po okresie rozbicia feudalnego zarówno w Polsce, jak i w Rosji kontynuowana była ochrona zasobów przyrodniczych: w Rosji w formie ukazów carskich, w Polsce - królewskimi statutami.

W okresie monarchii stanowej celem ochrony zasobów Rosji była już nie tylko ochrona własności panującego, ale także szersze interesy ogólnopaństwowe - zachowanie lasów zasiekowych ze względu na bezpieczeństwo zewnętrzne, podatki

53 Zob. M. Micińska-Bojarek, Obszary klęski ekologicznej Federacji Rosyjskiej - status prawny i programy naprawcze, „Prawo i Środowisko” 2014, nr 4.

54 М. М. Бринчук, op. cit., e-book: https://books.google.pl/. 
za pozyskiwanie zwierzyny, a więc regulacje niewystępujące $\mathrm{w}$ polskim porządku prawnym tej epoki.

Wraz z rozpoczęciem epoki przemysłowej pojawiły się pierwsze przepisy związane ograniczeniem emisji przemysłowych i karnej odpowiedzialności za szkody w środowisku odpowiadające duchem regulacjom zachodnim. Natomiast na fali rewolucji październikowej i nacjonalizacji ziemi weszły w życie nowe kodeksy i ustawy dotyczące gospodarowania poszczególnymi zasobami środowiska. Równolegle w Polsce po odzyskaniu niepodległości również nastąpiła intensyfikacja działań legislacyjnych.

Kolejny etap istotnych zmian w podejściu do kwestii środowiskowych, zarówno w Polsce, jak w i Rosji, przyniosła konferencja sztokholmska, a następnie okres transformacji ustrojowej rozpoczęty w obu krajach pod koniec lat 80. ubiegłego wieku.

Podsumowując historię ochrony środowiska w obu państwach, można zauważyć liczne analogie w genezie i rozwoju źródeł prawa, celów, przedmiotu i form regulacji. Widoczne jest też, że zewnętrzne impulsy prowadzące do zmian w prawie środowiskowym następowały w obu krajach mniej więcej równocześnie, powodowane ogólnoeuropejskimi przemianami technologicznymi, gospodarczymi, a następnie wzrastającym wpływem prawa międzynarodowego.

\section{BIBLIOGRAFIA}

Bazylow L., Historia Rosji, Warszawa 1996.

Blainey G., A Short History of the Twentieth Century, Pinguin Books, Australia 2005.

Boć J., Nowacki K., Samborska-Boć E., Ochrona środowiska, Wrocław 2008.

Бринчук М. М., Экологическое право. Учебник, КонсультантПлюс 2009. Булгаков М. Б., Ялбулганов А. А, Природоохранные акты: от «Русской правды» до петровских времен, „Государство и право” 1996, nr 2.

Czerska D., Sobronoje Ułożenije 1649 roku. Zagadnienia społeczno ustrojowe, Wrocław 1970. 
Gumilow L., Od Rusi do Rosji, Warszawa 1996.

Koranyi K., Powszechna historia prawa, Warszawa 1976.

Micińska-Bojarek M., Obszary klęski ekologicznej Federacji Rosyjskiej status prawny i programy naprawcze, "Prawo i Środowisko" 2014, nr 4.

Paczuski R., Prawo ochrony środowiska, Bydgoszcz 2000.

Płaza S., Historia prawa w Polsce na tle porównawczym, Kraków 1997. Powszechna historia państwa i prawa. Wybór tekstów źródtowych, wyboru dokonali M. J. Ptak i M. Kinstler, Wrocław 1999.

Sójka-Zielińska K., Historia prawa, Warszawa 1998.

Szczaniecki M., Powszechna historia państwa i prawa, Warszawa 2003.

Kontakt e-mail:

m.micinska@kpsw.edu.pl 